International Journal of
Food
Sciences
(IJF)

\begin{abstract}
PROBIOTIC PROPERTIES OF LACTIC ACID BACTERIA ISOLATED FROM "TCHOUKOU" TRADITIONAL MILK CHEESES PRODUCED IN SELECTED REGION OF NIGER.
\end{abstract}

Ibrahima Doumbouya, Dr Kevin Mbogo Omolo and Prof. Willis

Owino 


\section{PROBIOTIC PROPERTIES OF LACTIC ACID BACTERIA ISOLATED FROM "TCHOUKOU" TRADITIONAL MILK CHEESES PRODUCED IN SELECTED REGION OF NIGER.}

${ }^{a}$ Ibrahima Doumbouya

Department of Molecular Biology and Biotechnology, Pan African University Institute of

Basic Sciences, Technology and Innovation, (PAUSTI), Nairobi, Kenya.

Corresponding author email:doumbouya.ibrahima1@ students.jkuat.ac.ke;

${ }^{\mathrm{b}}$ Dr Kevin Mbogo Omolo

Department of Biochemistry, Jomo Kenyatta University of Agriculture and Technology

(JKUAT), Kenya.

kevin.mbogoo@gmail.com

${ }^{c}$ Prof. Owino O. Willis

Department of Food Sciences and Technology, Jomo Kenyatta University of Agriculture and Technology (JKUAT), Nairobi, Kenya.willis@agr.jkuat.ac.ke

\section{Abstract}

Purpose: The current study's aim is to evaluate the probiotic potential of lactic acid bacteria strains isolated from traditional "Tchoukou" milk cheeses produced in a selected region of Niger.

Methodology: Nine Samples were collected in selected regions of Niger (Tahoua, Maradi, and Zinder).Probiotic properties of isolated LAB were identified based on their acid tolerance, bile salt tolerance, auto-aggregation ability, simulated stomach and duodenum passage, simulated gastric juice survivability and their antimicrobial activities.

Findings: A total of eighteen strains were analysed in vitro for acid tolerance, bile tolerance, survival under simulated gastro-intestinal tract conditions and antimicrobial activity against index organisms. The results indicated that all seventeen strains exhibited a high viability after twenty-four hours of incubation at $\mathrm{pH} 2.5$ and $\mathrm{pH} 3$, but a decreased viability at $\mathrm{pH} 2.0$ in which only eight strains were able to survive, strain $\mathrm{C} 13$ failed to grow at the three different $\mathrm{pH}$. In this study, the isolates generally survived better after exposure to $0.3 \%$ bile salt. Also were able to survive exposure to simulated stomach and duodenum passage (SSDP) for three hours ranging from (89\%-100\%).All strains were able to survive under simulated gastric juice at different $\mathrm{pH}(2,2.5$ and 3). for auto-aggregation Only fifteen isolates showed the best auto-aggregation abilities ranging from (15-83\%) and the other two had less autoaggregation ability $(2-11 \%)$. The isolates showed diverse antimicrobial activity against the index organisms. Among the isolates, only three (C1, C2 and C9) could not inhibit any of the selected pathogens.

Unique contribution to theory, practice and policy: This study was conducted to characterize the probiotic properties of LAB isolate which could serve as a potential source for industries and commercial applications.

Keywords: Tchoukou, Probiotics, Lactic acid bacteria, Antimicrobial 


\section{INTRODUCTION}

Lactic acid bacteria (LAB) are an important microbial group in the food sector. They have been consumed in dairy products for a long time by people all over the world and most of them are considered as "generally recognized as safe" (GRAS) microorganisms since they are non-pathogenic, suitable for technological and industrial processes, resistant to acids and bile and able to produce antimicrobial substances(Reuben et al., 2020). Over the past decade, LAB has gained significant interest and is used widely as a probiotic (Reuben et al., 2020).Probiotics are an upcoming area for food companies, mainly in the dairy industry, with considerable potential for growth(Yadav et al., 2016).Probiotics are viable microorganisms that provide health effects when consumed. The minimum recommended amount of probiotic bacteria is to be at least $10^{6} \mathrm{cfu} / \mathrm{g}$ in the food product being fermented at the time of ingestion to provide their health benefits(Mahmoud et al., 2020). The growing acceptance of probiotic use has been due to their diverse effects, which include antimicrobial activities, anti-cancer, anti-oxidant and anti-allergic effects, lowering of blood lipids, and enhanced immune response, all of which depend on the strain.(Lee et al., 2014).

Probiotics have now many uses in human and animal health, especially in the management and prevention of diseases (Anandharaj et al, 2014). In the present day, probiotics are not only used as an enhancer of growth but also as a booster of the immune system and prevention of many illnesses (Del Piano et al.,2004). Probiotic food products due to their nutritive value and health sector in earlier times along with the therapeutic benefits are considered, and they have become the subject of extensive studies and commercial development(Smid et al., 2005).

Probiotics release a number of compounds, namely exopolysaccharides, organic acids and bacteriocins. The bacteriocins produced by probiotics have been demonstrated to antagonize pathogens (Smid et al., 2005).There is evidence of their role in the treatment of ulcerative colitis, necrotizing enterocolitis, pouchitis, severe infectious diarrhea, antibiotic-associated diarrhea, irritable bowel syndrome and Crohn's disease (Chong et al.,2014). An effective probiotic has to be viable, safe, tolerant to bile and gastric juices, capable of surviving in the gastrointestinal tract, and able to colonize and attach to epithelial cells in the gut (Lee et al.,2021). Phenol sensitivity is also an important selection characteristic, as gut bacteria can disrupt diet-derived amino acids, resulting in the generation of phenolic compounds (Lee et al., 2014). While researchers in other countries have characterized LAB probiotic strains from a variety of dairy products and food or animal sources. Disease breakouts are becoming increasingly recognized as a critical challenge to agriculture, human health, and economic development in many countries. Intestinal infections due to Escherichia coli, Campylobacter fetus subsp. jejuni, Clostridium perfringens and $C$. botulinum are common, however, antibiotics used to manage these diseases may induce and propagate antimicrobial resistant bacteria and resistance genes, (Aly et al., 2009). In addition, there is increasing interest in the use and, particularly, the overuse of antimicrobial drugs in human medicine, which may pose risks related to the spread of cross-resistance to antimicrobials in human medicine, (FAO/WHO/OIE 2006).

Artisanal "tchoukou" cheese has important organoleptic features that make it popular in Niger though limited data exist on the composition of this cheese microbiota. This study was build up on the study carried out by Mahamadou Rabiou et.al. (2021) who characterized 
lactic acid bacteria isolated from Tchoukou cheese sampled from three geographical locations in Southern Niger. Despite the growing interest in probiotics, there is not much scientific information on the functional properties of LAB isolated from traditional cheese (tchoukou), therefore, extensive studies are needed to assess probiotic properties of these LAB isolates for their possible application as probiotics in fermented products, our objective is to characterize the probiotic properties of lactic acid bacteria isolated from traditional cow's milk cheese (tchoukou) from a selected region of Niger and to profile the LAB bacteriocin gene.

\section{MATERIALS AND METHODS}

\section{Sample collection}

Nine (9) samples of cow's milk cheese were collected from three different regions of Niger (Tahoua, Maradi, and Zinder). In each location, three (3) samples were collected. The samples were aseptically packaged in ZIP lock bags and then coated in aluminium foil after drying. This form of packaging allowed the collected samples to be transported safely and in good shape for the intended purpose. LAB were isolated from the samples and characterized using phenotypic and biochemical characteristics as well as genotypic methods to determine the taxonomic placement of LAB isolates (Mamadou et al., 2021),

\section{In vitro determination of functional probiotic properties of the isolated LAB strains}

\section{Tolerance to low pH}

The low $\mathrm{pH}$ tolerance was assessed according to Mulaw et al $(, 2019)$, with modifications. Isolates were grown individually in MRS broth overnight at $37^{\circ} \mathrm{C}$ under anaerobic conditions. $1 \mathrm{ml}$ of the overnight isolate culture was inoculated into sterile MRS broth which was adjusted to $\mathrm{pH}$ values of $2.0,2.5$, and 3.0 using $1 \mathrm{~N} \mathrm{HCI}$. At $37^{\circ} \mathrm{C}$, each test tube was incubated for 24 hours. After an appropriate incubation period, $1 \mathrm{ml}$ of the culture was diluted in $9 \mathrm{ml}$ sterile ringer solution, prepared according to the manufacturer's instructions, and plated on MRS agar medium. Each inoculated plate was incubated at $37^{\circ} \mathrm{C}$ for 24 hours under anaerobic conditions. Each cultured colony was reported in colony forming units per milliliter $(\mathrm{CFU} / \mathrm{ml})$. A positive control consisting of regular MRS broth inoculated with the isolates was used (Grosu-Tudor et al.,2012). The survival rate was calculated as the percentage of LAB colonies grown on MRS agar relative to the initial bacterial concentration:

$$
\text { survival rate }(\%)=\frac{\log C F U N 1}{\log C F U N 0} \times 100
$$

Where $\mathrm{N}_{1}$ is the viable count of isolates after incubation and $\mathrm{N}_{0}$ is the initial viable count(Mulaw et al., 2019).

\section{Bile salt tolerance}

To assess the bile tolerance of acid-tolerant LAB (those grown only at $\mathrm{pH} 2.0,2.5$, and/or 3.0 ), the isolates were grown overnight in MRS broth sufficient cell suspension to give $10^{6}$ $\mathrm{CFU} / \mathrm{mL}$ concentration of each isolate was added into $10 \mathrm{~mL}$ of sterile MRS broth containing $0.3 \%$ of bile salts (Oxoid, UK). The broths were incubated for 24 hours and cell viability was determined by serial dilution and plating onto MRS agar after 24, and 48hours incubation and the number of LAB was estimated using colony forming units per milliliter (CFU/ml).

The rate of survival was calculated as the percentage of LAB colonies grown on MRS agar relative to the initial bacterial concentration: 
survival rate $(\%)=\frac{\log C F U N 1}{\log C F U N 0} \times 100$

Where $\mathrm{N}_{1}$ is the viable count of isolates after incubation and $\mathrm{N}_{0}$ is the initial viable count(Jose et al., 2015).

\section{Simulated gastric juice survivability test}

The simulated gastric juice was prepared according to (Corcoran et al., 2005), with modifications. Simulated gastric juice was formulated using pepsin $(3 \mathrm{~g} / \mathrm{l})$, and $1 \mathrm{ml}$ of each isolate was re-suspended in $5 \mathrm{ml}$ of simulated gastric juice at $\mathrm{pH} 2, \mathrm{pH} 2.5$ and $\mathrm{pH} 3$. This was followed by incubation at $37^{\circ} \mathrm{C}$ for $90 \mathrm{~min}$ with constant shaking at different time intervals $(0,30,60$ and $90 \mathrm{~min})$, after incubation the samples was taken and serially diluted, then plated on MRS agar plates and incubated at $37^{\circ} \mathrm{C}$ for 24 hours. The rate of survival was calculated as the percentage of LAB colonies grown on MRS agar relative to the initial bacterial concentration:

$$
\text { survival rate }(\%)=\frac{\log C F U N 1}{\log C F U N 0} \times 100
$$

Where $\mathrm{N}_{1}$ is the viable count of isolates after incubation and $\mathrm{N}_{0}$ is the initial viable count(Corcoran et al., 2005).

\section{Response to simulated stomach duodenum passage}

Response to simulated stomach duodenum passage was assess according to (Mathara et al., 2008), with modifications. Synthetic duodenum juice was prepared by completely dissolving $\mathrm{NaHCO}_{3}\left(6.4 \mathrm{~g} \mathrm{~L}^{-1}\right), \mathrm{KCl}\left(0.239 \mathrm{~g} \mathrm{~L}^{-1}\right)$, and $\mathrm{NaCl}\left(1.28 \mathrm{~g} \mathrm{~L}^{-1}\right)$ in distillate water. The $\mathrm{pH}$ was adjusted to 7.4 with $5 \mathrm{M} \mathrm{HCl}$ before sterilizing at $121^{0} \mathrm{C}$ for $15 \mathrm{~min}$. The bile salt solution was prepared by reconstituting $10 \mathrm{~g}$ of bile salt in $100 \mathrm{~mL}$ distillate water and sterilizing at $121^{\circ} \mathrm{C}$ for $15 \mathrm{~min} .4 \mathrm{ml}$ of bile salt solution was added to the culture in the flasks, followed by $17 \mathrm{~mL}$ of duodenum juice. After mixing, the initial count was determined by spread plating. The flasks were incubated at $37^{\circ} \mathrm{C}$. Samples were withdrawn after $1 \mathrm{~h}$ and viable counts were determined by spread plating. The flasks were further incubated at $37^{\circ} \mathrm{C}$. Samples were withdrawn after 2 hours to 3 hours, and counts were determined. The rate of survival was calculated as the percentage of LAB colonies grown on MRS agar relative to the initial bacterial concentration:

$$
\text { survival rate }(\%)=\frac{\log C F U N 1}{\log C F U N 0} \times 100
$$

Where $\mathrm{N}_{1}$ is the viable count of isolates after incubation and $\mathrm{N}_{0}$ is the initial viable count(Mathara et al., 2008).

\section{Auto aggregation assay}

The auto-aggregation was carried out according to (Balakrishna et al., 2013), with modifications. LAB isolates were cultured for 18 hours at $37^{\circ} \mathrm{C}$ in MRS broth. Cells were collected by centrifugation (15000rpm, $5 \mathrm{~min}$ ) and pellet was washed three times with sterile PBS. Next, the pellet was incubated at $37{ }^{\circ} \mathrm{C}$ for 5 hours. The optical density of the top layer suspension was analysed at 0 hours and 5 hours using UV spectrophotometer at $600 \mathrm{~nm}$ $\left(\mathrm{OD}_{600}\right)$. The auto-aggregation ability was calculated as follows:

$$
\text { Auto-aggregation ability }(\%)=\left(1-\mathrm{A}_{t} / \mathrm{A}_{0}\right) \times 100 \%
$$


Where $\mathrm{A}_{\mathrm{t}}$ is $\mathrm{OD}_{600} 5$ hours, and $\mathrm{A}_{0}$ is $\mathrm{OD}_{600}$ at 0 hours (Balakrishna et al., 2013).

\section{Antimicrobial activities of isolated probiotic against selected pathogenic bacteria.}

Antimicrobial activities analysis

Antimicrobial activity of isolates against pathogenic strains was assessed using agar well diffusion method according to (Ridwan et al., 2008), with modification. Test microorganisms were Escherichia coli ATCC25922, Staphylococcus aureus, ATCC25923, Pseudomonas ATCC27853, and Candida albicans, ATCC 90028.100 $\mu 1$ of the pathogen was spread over the nutrient agar plates. A $100 \mu \mathrm{l}$ of overnight grown LAB isolate was poured into a well on plates. Plates were allowed to dry and incubated at $37^{\circ} \mathrm{C}$ for 24 to 48 hours (Ridwan et al., 2008).

\section{Screening for bacteriocin genes in the isolates}

Specific primers were used to screen the selected bacteriocin genes in the isolates. Cultures grown overnight in $9 \mathrm{ml}$ MRS broth at $37^{\circ} \mathrm{C}$ were used for DNA extraction. About $1 \mathrm{ml}$ of overnight culture was centrifuged at $(15,000 \times \mathrm{g}, 5$ minutes, and the supernatant was discarded. Total gDNA was extracted using Quick-DNA ${ }_{\text {TM }}$ Fungal/Bacterial Miniprep Kit (Zymo Research, USA) according to manufacturer's protocols. The concentration and purity of each DNA sample were determined using a Nano Drop spectrophotometer (PCR max Lambda) at 260/280 and 260/230. The DNA integrity was analyzed by gel electrophoresis on a $1 \%$ agarose gel. Samples were stored at $-20^{\circ} \mathrm{C}$ for further analysis.

Screening for known bacteriocin genes, including those encoding Nisin, Pediocin and plantaricin was conducted using the specific primer, (table 1).

Table 1: Designed primers for bacteriocin genes

\begin{tabular}{|l|c|c|}
\hline Genes & Primers & Amplicon size (bp) \\
\hline Plantaricin & F: 5' ACCTGAAATAGCATTTAATTCACG 3' & 147 \\
\hline R: 5' AGTGTTCGACATGTTGTTGATG 3' & 165 \\
\hline Pediocin & F: 5' ACTTGGATTTGGTATCTGTTTCGA 3' \\
R: 5' 'TTTGATTTGGTTATTTGCTTACGTG 3' & 287 \\
\hline
\end{tabular}

PCR Amplification of target genes:

The PCR were conducted according to (Anandharaj et al., 2014) . using a total volume of 25 $\mu \mathrm{L}$, containing $12.5 \mu \mathrm{L}$ of Master Mix (GoTaq Green Master Mix, Promega, Madison, WI), $1 \mu \mathrm{L}$ each of forward and reverse primers, $8.5 \mu \mathrm{L}$ of nuclease-free water, and $2 \mu \mathrm{L}$ of DNA template using a thermal cycler (SimpliAmp Thermal Cycler, Thermo Fisher Scientific, Waltham, MA). PCR conditions, the initial denaturation was at $94^{\circ} \mathrm{C}$ for 60 seconds followed by annealing temperature of $56^{\circ} \mathrm{C}$ for 60 seconds, 34 cycles of elongation at $72^{\circ} \mathrm{C}$ for 1 minute and final hold at $4^{\circ} \mathrm{C}$ indefinitely. Agarose gel was prepared to visualise PCR amplicon products using a 100bp ladder to estimate the products size.

\section{Statistical Analysis}

All data are revealed as mean value \pm standard error from triplicate experiments, SPSS (25 version) was used .The results of each analyse were compared with an appropriate control 
International Journal of Food Sciences

2789-7680 (online)

Vol. 5, Issue 1, No. 1, pp 1 - 15, 2022

www.iprjb.org

and statistical analysis was performed using the unpaired two-tailed $t$-test at a significance level of $P<0.05$.

\section{RESULTS AND DISCUSSION}

\section{Tolerance to low pH}

Acid tolerance is an essential selection factor for potential probiotics. Probiotic strain has to be able to survive the acidic conditions of the stomach. (Yadav et al., 2016). The ability of 18 LAB strains ( $\mathrm{C} 1$ to $\mathrm{C} 18)$ from traditional cow's milk cheese produce in Niger to tolerate low $\mathrm{pH}$ values of 2.0, 2.5 and 3 for 24 hours is shown in (Table 2). Seventeen of these strains except $\mathrm{C} 13$, showed survival rates of at least from $75 \%$ to $88 \%$ at $\mathrm{pH} 2.5$, whereas at $\mathrm{pH} 2.0$ only 8 strains(C3,C4,C5,C6,C7,C8,C11 and C17) showed survival rate from $51 \%$ to $65 \%$ and no viable cells were detected for 9 strains $(\mathrm{C} 1, \mathrm{C} 2, \mathrm{C} 9, \mathrm{C} 10, \mathrm{C} 12, \mathrm{C} 14, \mathrm{C} 15, \mathrm{C} 16$, and C18) after exposure for 24 hours at $\mathrm{pH} 2$ (table 2). seventeen LAB isolates (C1,C2,C3,C4,C5,C6,C7,C8, $\mathrm{C} 9, \mathrm{C} 10, \mathrm{C} 11, \mathrm{C} 12, \mathrm{C} 14, \mathrm{C} 15, \mathrm{C} 16$, and $\mathrm{C} 18)$ has showed survival rate from $76 \%$ to $94 \%$ at $\mathrm{pH}$ $3, .($ table 2$)$

Table 2: The Growth of the LAB under $\mathrm{pH} 2,2.5$, and 3. Data expressed as Mean $\pm \mathrm{SE}$ of the Mean of triplicate experiments. Values in bracket represent the percentage survival rate of each isolate.

\begin{tabular}{lcccccc}
\hline \multirow{2}{*}{$\begin{array}{l}\text { Strain } \\
\text { Code }\end{array}$} & \multicolumn{2}{c}{$\mathbf{p H = 2}$} & \multicolumn{2}{c}{$\mathbf{p H}=\mathbf{2 . 5}$} & \multicolumn{2}{c}{$\mathbf{p H = 3}$} \\
\cline { 2 - 7 } C1 & $7.50 \pm 0.01$ & $0.00 \pm 0.00(0)$ & $8.79 \pm 0.03$ & $7.26 \pm 0.04(83)$ & $9.56 \pm 0.06$ & $8.36 \pm 0.01(87)$ \\
C2 & $7.33 \pm 0.01$ & $0.00 \pm 0.00(0)$ & $8.72 \pm 0.05$ & $7.51 \pm 0.06(86)$ & $9.77 \pm 0.03$ & $8.50 \pm 0.06(87)$ \\
C3 & $8.86 \pm 0.02$ & $5.04 \pm 0.01(57)$ & $9.39 \pm 0.13$ & $7.06 \pm 0.02(75)$ & $10.62 \pm 0.04$ & $8.06 \pm 0.02(76)$ \\
C4 & $8.36 \pm 0.12$ & $5.39 \pm 0.08(64)$ & $9.80 \pm 0.03$ & $7.55 \pm 0.06(77)$ & $10.69 \pm 0.01$ & $8.78 \pm 0.02(82)$ \\
C5 & $8.59 \pm 0.04$ & $5.59 \pm 0.04(65)$ & $9.73 \pm 0.01$ & $7.35 \pm 0.03(76)$ & $10.59 \pm 0.04$ & $8.22 \pm 0.07(78)$ \\
C6 & $8.68 \pm 0.01$ & $5.23 \pm 0.05(60)$ & $9.60 \pm 0.02$ & $7.47 \pm 0.02(78)$ & $10.68 \pm 0.01$ & $8.40 \pm 0.04(79)$ \\
C7 & $7.37 \pm 0.12$ & $4.24 \pm 0.08(58)$ & $8.73 \pm 0.02$ & $7.25 \pm 0.02(83)$ & $9.67 \pm 0.04$ & $8.22 \pm 0.03(85)$ \\
C8 & $8.68 \pm 0.04$ & $4.40 \pm 0.07(51)$ & $9.78 \pm 0.02$ & $7.40 \pm 0.04(76)$ & $10.86 \pm 0.01$ & $8.46 \pm 0.02(78)$ \\
C9 & $0.00 \pm 0.00$ & $0.00 \pm 0.00(0)$ & $8.66 \pm 0.06$ & $7.24 \pm 0.05(84)$ & $9.55 \pm 0.05$ & $8.31 \pm 0.03(87)$ \\
C10 & 7.090 .03 & $0.00 \pm 0.00(0)$ & $8.73 \pm 0.01$ & $7.66 \pm 0.02(88)$ & $9.11 \pm 0.55$ & $8.55 \pm 0.02(94)$ \\
C11 & $8.55 \pm 0.04$ & $5.02 \pm 0.01(59)$ & $9.60 \pm 0.03$ & $7.30 \pm 0.03(76)$ & $10.64 \pm 0.02$ & $8.28 \pm 0.04(78)$ \\
C12 & $0.00 \pm 0.00$ & $0.00 \pm 0.00(0)$ & $8.91 \pm 0.01$ & $7.43 \pm 0.02(83)$ & $9.97 \pm 0.01$ & $8.29 \pm 0.06(83)$ \\
C13 & $0.00 \pm 0.00$ & $0.00 \pm 0.00(0)$ & $0.00 \pm 0.00$ & $0.00 \pm 0.00(0)$ & $0.00 \pm 0.00$ & $0.00 \pm 0.00(0)$ \\
C14 & $7.83 \pm 0.02$ & $0.00 \pm 0.00(0)$ & $8.48 \pm 0.04$ & $7.37 \pm 0.04(87)$ & $10.46 \pm 0.04$ & $8.43 \pm 0.02(81)$ \\
C15 & $7.45 \pm 0.11$ & $0.00 \pm 0.00(0)$ & $8.49 \pm 0.06$ & $7.48 \pm 0.05(88)$ & $10.50 \pm 0.05$ & $8.57 \pm 0.02(82)$ \\
C16 & $0.00 \pm 0.00$ & $0.00 \pm 0.00(0)$ & $8.21 \pm 0.07$ & $7.02 \pm 0.01(86)$ & $10.31 \pm 0.04$ & $8.02 \pm 0.01(78)$ \\
C17 & $7.10 \pm 0.03$ & $4.15 \pm 0.05(58)$ & $8.84 \pm 0.02$ & $7.12 \pm 0.04(81)$ & $10.15 \pm 0.05$ & $8.17 \pm 0.02(80)$ \\
C18 & $7.49 \pm 0.06$ & $0.00 \pm 0.00(0)$ & $8.23 \pm 0.08$ & $7.15 \pm 0.05(87)$ & $10.35 \pm 0.04$ & $8.22 \pm 0.03(79)$ \\
\hline
\end{tabular}

Bile salt tolerance

Seventeen (17) LAB isolates (C1,C2,C3,C4,C5,C6,C7,C8,C9,C10,C11,C12,C13,C14,C15,

$\mathrm{C} 16, \mathrm{C} 17)$ were able to survive above $80 \%$ in the presence of $0.3 \%$ of bile salt. Isolate $\mathrm{C} 12$ was the most tolerant with $93 \%$ survival rate followed by isolates $\mathrm{C} 15$ with $92 \%$ and $\mathrm{C} 14$ with $91 \%$ survival rates, after 24 hours incubation. After 48 hours incubation all the isolate were able to survive above $95 \%$ in the presence of $0.3 \%$ of bile salt. Isolate $\mathrm{C} 17$ was the most 
International Journal of Food Sciences

2789-7680 (online)

Vol. 5, Issue 1, No. 1, pp 1 - 15, 2022

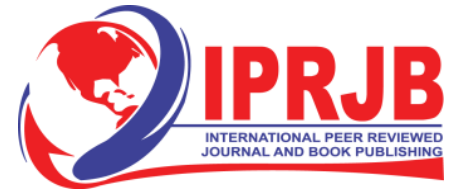

www.iprjb.org

tolerant with $105 \%$ survival rate followed by isolates $\mathrm{C} 11, \mathrm{C} 12$ with $103 \%$ and $\mathrm{C} 2, \mathrm{C} 5, \mathrm{C} 6$, C10, 15 with $102 \%$ and C9, C14 with $100 \%$ survival rates in presence of bile salt are present in (Table 3)

Table 3: Growth of the LAB under $0.3 \%$ of bile salt. Data expressed as Mean \pm SE of the Mean of triplicate experiments. Values in bracket represent the percentage survival rate of each isolate.

\begin{tabular}{llll}
\hline $\begin{array}{l}\text { Strain } \\
\text { Code }\end{array}$ & \multicolumn{3}{c}{$\mathbf{0 . 3 \% \text { bile salt }}$} \\
\cline { 2 - 4 } Chours & 24 hours & 48 hours \\
\hline C1 & $8.81 \pm 0.06$ & $7.54 \pm 0.10(86)$ & $8.37 \pm 0.13(95)$ \\
C2 & $8.90 \pm 0.04$ & $7.49 \pm 0.11(84)$ & $8.95 \pm 0.02(102)$ \\
C3 & $9.05 \pm 0.02$ & $7.25 \pm 0.08(80)$ & $8.62 \pm 0.02(98)$ \\
C4 & $9.04 \pm 0.01$ & $7.42 \pm 0.10(82)$ & $8.73 \pm 0.02(99)$ \\
C5 & $9.09 \pm 0.03$ & $8.02 \pm 0.01(88)$ & $9.03 \pm 0.01(102)$ \\
C6 & $9.20 \pm 0.07$ & $7.89 \pm 0.04(86)$ & $8.97 \pm 0.03(102)$ \\
C7 & $9.14 \pm 0.05$ & $7.64 \pm 0.07(84)$ & $8.49 \pm 0.14(96)$ \\
C8 & $8.45 \pm 0.15$ & $7.47 \pm 0.10(88)$ & $8.46 \pm 0.12(96)$ \\
C9 & $9.13 \pm 0.04$ & $7.39 \pm 0.13(81)$ & $8.80 \pm 0.01(100)$ \\
C10 & $9.06 \pm 0.02$ & $7.77 \pm 0.07(86)$ & $8.97 \pm 0.02(102)$ \\
C11 & $9.10 \pm 0.03$ & $8.08 \pm 0.03(89)$ & $9.09 \pm 0.03(103)$ \\
C12 & $8.64 \pm 0.11$ & $8.03 \pm 0.01(93)$ & $9.05 \pm 0.02(103)$ \\
C13 & $8.97 \pm 0.02$ & $7.29 \pm 0.10(81)$ & $8.52 \pm 0.05(97)$ \\
C14 & $8.52 \pm 0.18$ & $7.75 \pm 0.03(91)$ & $8.84 \pm 0.02(100)$ \\
C15 & $8.68 \pm 0.09$ & $7.97 \pm 0.01(92)$ & $8.98 \pm 0.01(102)$ \\
C16 & $8.90 \pm 0.04$ & $7.34 \pm 0.11(80)$ & $8.70 \pm 0.01(99)$ \\
C17 & $8.97 \pm 0.03$ & $7.19 \pm 0.07(80)$ & $9.26 \pm 0.09(105)$ \\
\hline
\end{tabular}

Simulated gastric juice survivability

The effect of simulated gastric juice at $\mathrm{pH} \mathrm{2.0,2.5} \mathrm{and} 3$ on LAB isolates is presented in (Table 4).only isolates $\mathrm{C} 12$ failed to survive in simulated gastric juice at $\mathrm{pH} 2.0$ after 60minutes and 90 minutes of incubation, and the rest of 16 isolate were able to survive above $50 \%$. Isolate $\mathrm{C} 1$ was the most tolerant at $\mathrm{pH} 2$ with $69 \%$, following by $\mathrm{C} 17$ with $65 \%$, and C10 with 63\% (table 4). At pH 2.5 all the 17 isolate were able to survive above $81 \%$, isolate $\mathrm{C} 1$ is most tolerant with $89 \%$, followed by $\mathrm{C} 15$ with $87 \%, \mathrm{C} 14, \mathrm{C} 13, \mathrm{C} 12$, and $\mathrm{C} 7$ with $86 \%$, $\mathrm{C} 4$ with $85 \%, \mathrm{C} 16, \mathrm{C} 11, \mathrm{C} 5, \mathrm{C} 2$ with $84 \%$ and $\mathrm{C} 8, \mathrm{C} 10$ with $82 \%$ (table 4) .whereas all the isolates were able to survive at $\mathrm{pH} \mathrm{3}$, the survival rate were above $94 \%$.but the isolate $\mathrm{C} 13$ was the most tolerant at $\mathrm{pH} 3$ with $105 \%$ after 60 and 90min of incubation, followed by $\mathrm{C} 14$, C10, C7, C2, with 104\%, C4 with 103\%, C8, C16 with 102\%, C17 with $101 \%$ and C12 with 100\% (table 4) 
Table 4: The Growth of the LAB under $\mathrm{pH} 2,2.5$, and 3 of simulated gastric juice. Data expressed as Mean \pm SE of the Mean of triplicate experiments. Values in bracket represent the percentage survival rate of each isolate.

\begin{tabular}{|c|c|c|c|c|c|c|}
\hline \multirow{2}{*}{$\begin{array}{l}\text { Strain } \\
\text { Code }\end{array}$} & \multicolumn{2}{|c|}{$\mathrm{pH}=2$} & \multicolumn{2}{|c|}{$\mathrm{pH}=2.5$} & \multicolumn{2}{|c|}{$\mathrm{pH}=3$} \\
\hline & Ohour & 24hours & Ohour & 24hours & Ohour & 24hours \\
\hline \multicolumn{7}{|l|}{$\mathrm{C} 1$} \\
\hline \multirow{2}{*}{$\mathrm{C} 2$} & $7.50 \pm 0.17$ & $5.14 \pm 0.12(69)$ & $8.94 \pm 0.02$ & $7.96 \pm 0.02(89)$ & $10 \pm 0.00$ & $9.90 \pm 0.03(99)$ \\
\hline & $7.94 \pm 0.05$ & $4.24 \pm 0.08(53)$ & $9.04 \pm 0.01$ & $7.55 \pm 0.06(84)$ & $9.54 \pm 0.18$ & $9.95 \pm 0.02(104)$ \\
\hline $\mathrm{C} 3$ & $8.05 \pm 0.02$ & $4.74 \pm 0.09$ (59) & $9.05 \pm 0.02$ & $7.34 \pm 0.12$ & $10.05 \pm 0.02$ & $9.70 \pm 0.09(97)$ \\
\hline $\mathrm{C} 4$ & $8.03 \pm 0.02$ & $4.10 \pm 0.03(51)$ & $9.04 \pm 0.01$ & $7.67 \pm 0.08$ & $9.55 \pm 0.18$ & $9.82 \pm 0.03(103)$ \\
\hline $\mathrm{C} 5$ & $8.09 \pm 0.03$ & $4.40 \pm 0.03(54)$ & $9.13 \pm 0.02$ & $7.66 \pm 0.02(84)$ & $10.09 \pm 0.03$ & $9.90 \pm 0.03(98)$ \\
\hline C6 & $8.20 \pm 0.07$ & $4.15 \pm 0.05(51)$ & $9.55 \pm 0.05$ & $7.96 \pm 0.01(83)$ & $10.20 \pm 0.07$ & $9.97 \pm 0.01(98)$ \\
\hline $\mathrm{C} 7$ & $8.08 \pm 0.03$ & $4.50 \pm 0.03(56)$ & $9.04 \pm 0.01$ & $7.76 \pm 0.03(86)$ & $9.54 \pm 0.19$ & $9.93 \pm 0.03(104)$ \\
\hline $\mathrm{C} 8$ & $7.95 \pm 0.02$ & $4.65 \pm 0.02(58)$ & $8.95 \pm 0.02$ & $7.38 \pm 0.13(82)$ & $9.64 \pm 0.09$ & $9.88 \pm 0.04(102)$ \\
\hline C9 & $8.13 \pm 0.04$ & $4.67 \pm 0.01(57)$ & $9.33 \pm 0.02$ & $7.53 \pm 0.09(81)$ & $10.13 \pm 0.04$ & $9.97 \pm 0.01(98)$ \\
\hline $\mathrm{C} 10$ & $7.99 \pm 0.03$ & $5.02 \pm 0.01(63)$ & $9.04 \pm 0.01$ & $7.37 \pm 0.11(82)$ & $9.55 \pm 0.18$ & $9.92 \pm 0.02(104)$ \\
\hline $\mathrm{C} 11$ & $8.10 \pm 0.03$ & $4.15 \pm 0.05(51)$ & $9.15 \pm 0.02$ & $7.73 \pm 0.01$ & $10.11 \pm 0.03$ & $10.00 \pm 0.00(99)$ \\
\hline $\mathrm{C} 12$ & $7.82 \pm 0.05$ & $0.00 \pm 0.00(0)$ & $8.96 \pm 0.01$ & $7.75 \pm 0.01(86)$ & $9.99 \pm 0.01$ & $\begin{array}{l}10.00 \pm 0.00 \\
(100)\end{array}$ \\
\hline $\mathrm{C} 13$ & $8.02 \pm 0.01$ & $4.53 \pm 0.02(56)$ & $9.02 \pm 0.01$ & $7.76 \pm 0.03$ & $9.47 \pm 0.20$ & $9.99 \pm 0.01(105)$ \\
\hline $\mathrm{C} 14$ & $8.02 \pm 0.01$ & $4.64 \pm 0.05(58)$ & $9.02 \pm 0.01$ & $7.77 \pm 0.01$ & $9.52 \pm 0.18$ & $9.92 \pm 0.03(104)$ \\
\hline $\mathrm{C} 15$ & $7.91 \pm 0.01$ & $3.94 \pm 0.02(50)$ & $9.14 \pm 0.05$ & $7.95 \pm 0.02(87)$ & $9.98 \pm 0.01$ & $9.43 \pm 0.02(94)$ \\
\hline $\mathrm{C} 16$ & $7.91 \pm 0.04$ & $4.43 \pm 0.02(56)$ & $9.07 \pm 0.02$ & $7.60 \pm 0.05(84)$ & $9.76 \pm 0.09$ & $9.93 \pm 0.01(102)$ \\
\hline $\mathrm{C} 17$ & $8.02 \pm 0.02$ & $5.18 \pm 0.06(65)$ & $9.12 \pm 0.02$ & $7.60 \pm 0.03(83)$ & $9.98 \pm 0.03$ & $\begin{array}{l}10.12 \pm 0.06 \\
(101)\end{array}$ \\
\hline
\end{tabular}

\section{Response to simulated stomach duodenum passage}

The LAB isolates were tested under conditions of simulated stomach duodenum passage to determine their survival. All the isolates showed survival rates of 95 to $103 \%$ after 1 hour incubation under simulated stomach duodenum passage, $\mathrm{C} 1$ had a high survival rate after 1hour with $103 \%$, followed by $\mathrm{C} 12$ with $102 \%, \mathrm{C} 4, \mathrm{C} 6, \mathrm{C} 8, \mathrm{C} 11, \mathrm{C} 13, \mathrm{C} 14, \mathrm{C} 16$ with $100 \%$ (table 5). And they also showed survival rate ranging from 89 to $100 \%$ after 3 hours incubation (Table 5). The strains C7 had significantly higher survival rate with $100 \%$ while the other isolates namely $\mathrm{C} 1, \mathrm{C} 2, \mathrm{C} 3, \mathrm{C} 4, \mathrm{C} 5, \mathrm{C} 6, \mathrm{C} 8, \mathrm{C} 9, \mathrm{C} 10, \mathrm{C} 11, \mathrm{C} 12, \mathrm{C} 13, \mathrm{C} 14, \mathrm{C} 15$, $\mathrm{C} 16, \mathrm{C} 17$ had survival rates of less than $100 \%$ and after 2hours incubation. This suggests that they can tolerate the conditions of the stomach and can therefore be potent probiotics. 
Table 5: The Growth (percentage) of the LAB under simulated stomach duodenum condition. Data expressed as Mean \pm SE of the Mean of duplicate experiments. Values in bracket represent the percentage survival rate of each isolate.

\begin{tabular}{lcccc}
\hline Strain Code & 0hour & 1hour & 2hours & 3hours \\
\hline C1 & $6.73 \pm 0.01$ & $6.98 \pm 0.00(103)$ & $6.29 \pm 0.00(93)$ & $6.43 \pm 0.02(96)$ \\
C2 & $6.70 \pm 0.07$ & $6.73 \pm 0.01(98)$ & $6.62 \pm 0.01(97)$ & $6.59 \pm 0.03(97)$ \\
C3 & $6.94 \pm 0.01$ & $6.61 \pm 0.00(95)$ & $6.19 \pm 0.00(89)$ & $6.47 \pm 0.01(93)$ \\
C4 & $6.64 \pm 0.08$ & $6.83 \pm 0.00(100)$ & $6.25 \pm 0.01(91)$ & $6.39 \pm 0.01(93)$ \\
C5 & $7.15 \pm 0.05$ & $6.49 \pm 0.00(93)$ & $6.82 \pm 0.01(98)$ & $6.44 \pm 0.01(93)$ \\
C6 & $6.91 \pm 0.00$ & $6.88 \pm 0.00(100)$ & $6.75 \pm 0.03(99)$ & $6.71 \pm 0.00(97)$ \\
C7 & $6.90 \pm 0.01$ & $6.43 \pm 0.01(93)$ & $6.67 \pm 0.01(97)$ & $6.89 \pm 0.01(100)$ \\
C8 & $6.97 \pm 0.01$ & $6.91 \pm 0.00(100)$ & $6.89 \pm 0.00(99)$ & $6.23 \pm 0.01(89)$ \\
C9 & $6.91 \pm 0.01$ & $6.57 \pm 0.01(95)$ & $6.38 \pm 0.00(92)$ & $6.22 \pm 0.01(90)$ \\
C10 & $7.07 \pm 0.02$ & $6.91 \pm 0.01(97)$ & $6.65 \pm 0.02(94)$ & $6.42 \pm 0.01(90)$ \\
C11 & $7.03 \pm 0.01$ & $7.02 \pm 0.01(100)$ & $6.64 \pm 0.00(94)$ & $6.72 \pm 0.01(95)$ \\
C12 & $6.43 \pm 0.15$ & $6.98 \pm 0.01(102)$ & $6.69 \pm 0.01(98)$ & $6.20 \pm 0.01(90)$ \\
C13 & $6.90 \pm 0.02$ & $6.94 \pm 0.01(100)$ & $6.76 \pm 0.00(97)$ & $6.56 \pm 0.01(95)$ \\
C14 & $7.03 \pm 0.01$ & $7.01 \pm 0.00(100)$ & $6.69 \pm 0.01(95)$ & $6.42 \pm 0.01(91)$ \\
C15 & $6.93 \pm 0.01$ & $6.72 \pm 0.01(97)$ & $6.25 \pm 0.00(90)$ & $6.43 \pm 0.01(93)$ \\
C16 & $6.86 \pm 0.02$ & $6.95 \pm 0.01(100)$ & $6.10 \pm 0.00(88)$ & $6.41 \pm 0.01(93)$ \\
C17 & $7.00 \pm 0.00$ & $6.78 \pm 0.00(97)$ & $6.39 \pm 0.00(91)$ & $6.70 \pm 0.01(96)$ \\
\hline
\end{tabular}

\section{Auto aggregation assay}

The auto-aggregation abilities of all the LAB strains studied are shown in Table 6. The results indicated that each strain can auto aggregate. Among these probiotic strains, C9 showed the highest auto aggregation percentage of $83 \%$, followed by $\mathrm{C} 1$ with $73 \%$, C8 with $61 \%, \mathrm{C} 17$ with $53 \%, \mathrm{C} 16$ with $42 \%$, C6 with $36 \%$, C7 with $34 \%$, C4 with $29 \%, \mathrm{C} 2, \mathrm{C} 10, \mathrm{C} 11$ with $28 \%$ (table 6). Five (5) strains had less auto-aggregation abilities; C3, C12, C13, C14 and C15 ranging between $12 \%$, and $19 \%$. Isolate, $\mathrm{C} 5$ had auto-aggregation ability of $2 \%$ (autoaggregation percentage $<10 \%$ ). 
Table 6: Auto-aggregation ability (percentage) of the isolated LAB. Data expressed as Mean \pm SE of the Mean of triplicate experiments. Values in bracket represent the percentage of auto-aggregation abilities of each isolate

\begin{tabular}{lcc}
\hline Strain Code & Ohour & 5hours \\
\hline C1 & $0.68 \pm 0.08$ & $0.17 \pm 0.02(73)$ \\
C2 & $2.02 \pm 0.13$ & $1.46 \pm 0.13(28)$ \\
C3 & $1.13 \pm 0.15$ & $1.00 \pm 0.14(12)$ \\
C4 & $2.31 \pm 0.06$ & $1.63 \pm 0.01(29)$ \\
C5 & $1.63 \pm 0.22(2)$ \\
C6 & $1.66 \pm 0.11$ & $1.54 \pm 0.17(36)$ \\
C7 & $2.36 \pm 0.09$ & $1.33 \pm 0.27(34)$ \\
C8 & $2.00 \pm 0.03$ & $0.82 \pm 0.04(61)$ \\
C9 & $2.08 \pm 0.05$ & $0.08 \pm 0.01(83)$ \\
C10 & $0.48 \pm 0.13$ & $1.63 \pm 0.12(28)$ \\
C11 & $2.27 \pm 0.02$ & $1.72 \pm 0.16(28)$ \\
C12 & $2.38 \pm 0.05$ & $1.79 \pm 0.10(19)$ \\
C13 & $2.20 \pm 0.06$ & $1.93 \pm 0.01(16)$ \\
C14 & $1.60 \pm 0.16$ & $1.68 \pm 0.03(15)$ \\
C15 & $2.28 \pm 0.03$ & $1.32 \pm 0.09(42)$ \\
C16 & $2.04 \pm 0.12$ & $1.11 \pm 0.08(53)$ \\
C17 & $2.29 \pm 0.11$ & \\
\hline
\end{tabular}

\section{Antimicrobial activities analysis}

The LAB isolates were also tested for antimicrobial activity against indicator organisms (Escherichia coli ATCC25922, Staphylococcus aureus ATCC25923, and Pseudomonas ATCC27853 and Candida albicans ATCC 90028,). The cell-free supernatants from different Lactobacillus strains inhibited the growth of indicator organisms as shown by inhibition zone results (Table 7). Among the test strains isolate $\mathrm{C} 17$ showed the highest antibacterial activity against $E$. coli with $(21 \pm 0.34 \mathrm{~mm})$, strains $\mathrm{C} 12,(19 \pm 0.34 \mathrm{~mm})$, followed by C16(18 $\pm 0.34 \mathrm{~mm}), \mathrm{C} 7(15 \pm 0.34 \mathrm{~mm}), \mathrm{C} 5, \mathrm{C} 10, \mathrm{C} 13, \mathrm{C} 14 \quad(14.5 \pm 0.17 \mathrm{~mm}), \mathrm{C} 11 \quad(13.5 \pm 0.17 \mathrm{~mm})$ and $\mathrm{C} 17(24.5 \pm 0.17 \mathrm{~mm})$ has showed a higher antibacterial activity against staphylococcus aureus. Followed by strains C14 $(23.5 \pm 0.51 \mathrm{~mm})$, C15 $(22 \pm 0.34 \mathrm{~mm})$, C13 $(21 \pm 0.34 \mathrm{~mm})$, C12, C16 $(20.5 \pm 0.17 \mathrm{~mm})$. The strains showed the highest antibacterial activity against pseudomonas ranging from $18.5 \pm 0.51$ to $26 \pm 0.34 \mathrm{~mm}$ with $\mathrm{C} 8$ which has showed highest antagonistic activity $(26 \pm 0.34 \mathrm{~mm})$. They also showed the antibacterial activity against candida albicans from $11.5 \pm 0.17$ to $24.5 \pm 0.17 \mathrm{~mm}$. (Table 7) 
International Journal of Food Sciences

2789-7680 (online)

Vol. 5, Issue 1, No. 1, pp 1 - 15, 2022

www.iprjb.org

Table 7: Antimicrobial effects of the strains against selected pathogens, 7.5 represent the diameter of halo in milimeter.

\begin{tabular}{lllll}
\hline Strain code & E.coli & $\begin{array}{l}\text { Staphylo } \\
\text { coccus } \\
\text { aureus }\end{array}$ & $\begin{array}{l}\text { Pseudo } \\
\text { monas }\end{array}$ & $\begin{array}{l}\text { Candida } \\
\text { albicans }\end{array}$ \\
\hline C1 & $7.5 \pm 0.00$ & $7.5 \pm 0.00$ & $7.5 \pm 0.00$ & $7.5 \pm 0.00$ \\
C2 & $7.5 \pm 0.00$ & $7.5 \pm 0.00$ & $7.5 \pm 0.00$ & $7.5 \pm 0.00$ \\
C3 & $12 \pm 0.34$ & $16 \pm 0.34$ & $22 \pm 1.03$ & $18 \pm 0.34$ \\
C4 & $13 \pm 0.34$ & $7.5 \pm 0.00$ & $20.5 \pm 0.51$ & $14.5 \pm 0.86$ \\
C5 & $14.5 \pm 0.17$ & $14.5 \pm 0.17$ & $18.5 \pm 0.51$ & $19 \pm 0.34$ \\
C6 & $12 \pm 0.34$ & $12.5 \pm 0.86$ & $21 \pm 0.34$ & $17 \pm 0.34$ \\
C7 & $15 \pm 0.34$ & $12 \pm 0.34$ & $25.5 \pm 0.17$ & $17.5 \pm 0.17$ \\
C8 & $11 \pm 0.34$ & $19.5 \pm 0.17$ & $26 \pm 0.34$ & $14 \pm 0.34$ \\
C9 & $7.5 \pm 0.00$ & $7.5 \pm 0.00$ & $7.5 \pm 0.00$ & $7.5 \pm 0.00$ \\
C10 & $14 \pm 0.69$ & $16.5 \pm 0.51$ & $25.5 \pm 0.17$ & $11 \pm 0.34$ \\
C11 & $13.5 \pm 0.17$ & $19 \pm 0.34$ & $24 \pm 0.34$ & $17.5 \pm 0.17$ \\
C12 & $19 \pm 0.34$ & $20.5 \pm 0.17$ & $23.5 \pm 0.51$ & $11.5 \pm 0.17$ \\
C13 & $14.5 \pm 0.17$ & $21 \pm 0.34$ & $23.5 \pm 0.86$ & $11 \pm 0.34$ \\
C14 & $14.5 \pm 0.17$ & $23.5 \pm 0.51$ & $22 \pm 0.69$ & $11.5 \pm 0.51$ \\
C15 & $11.5 \pm 0.17$ & $22 \pm 0.34$ & $22.5 \pm 0.17$ & $22.5 \pm 0.17$ \\
C16 & $18 \pm 0.34$ & $20.5 \pm 0.17$ & $21 \pm 0.34$ & $24.5 \pm 0.17$ \\
C17 & $21 \pm 0.34$ & $24.5 \pm 0.17$ & $23 \pm 0.34$ & $22.5 \pm 0.17$ \\
\hline
\end{tabular}

\section{Screening for bacteriocin genes}

The isolates were screened for selected bacteriocin genes (figure 1). All the isolates were negative for Nisin gene and Pediocin gene. However, all the LAB strains were positive for the bacteriocins, plantaricin gene (147 bp) (figure 1). Furthermore, the BLAST search of the plantaricin sequence for the strain confirmed the similarity of the detected plantaricin gene.

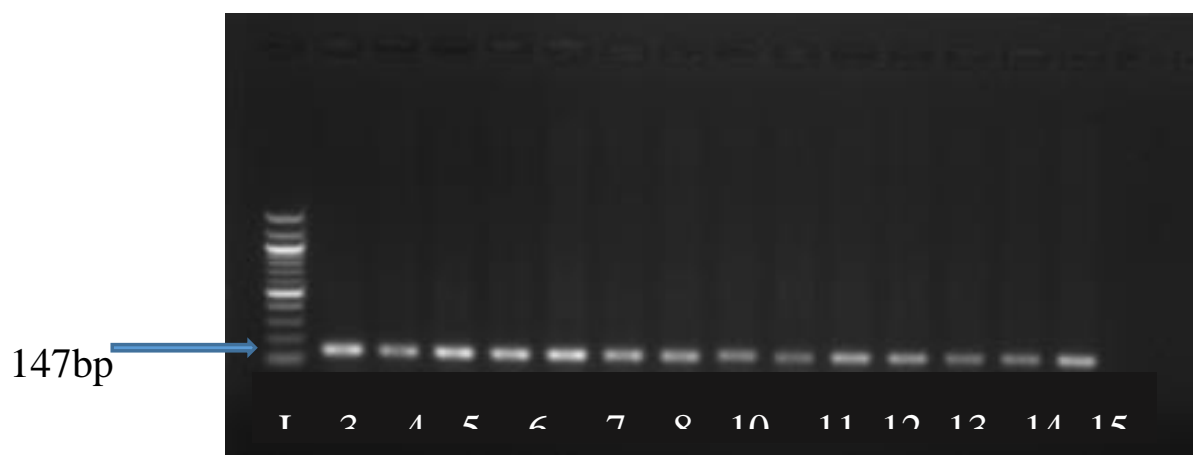

Figure 1: PCR bands for plantaricin 


\section{Discussion}

Lactic acid bacterial (LAB) strains are bacteria that are advantageous to the body. They're common in the healthy gut microbiota and can be found in a variety of fermented dairy products including cheese and fermented milk (Tan et al., 2013). Low pH, bile salts, and digesting conditions are the key elements determining probiotic bacteria's capacity to survive in the GI tract, which is one of the most sought features.(Tan et al., 2013). The probiotic characteristics of seventeen LAB strains isolated from cheese samples produced in Niger were studied. The most frequent way for determining the viability and activity of probiotic bacteria in the small intestine and stomach is to assess their tolerance to acidic conditions. A prior study (Azat et al., 2016) found that the growth rate at $\mathrm{pH} 3.0$ is regarded as an excellent acid resistance for the chosen probiotic strains. All the isolates in this study were capable of tolerating $\mathrm{pH} 3.0$ with a survival percentage of more than $70 \%$, qualifying the isolates to be classified as acid-tolerant LAB strains. Only 8 isolates showed tolerance to $\mathrm{pH} 2$ for $24 \mathrm{~h}$ (Table 2). Suggesting that the $8 \mathrm{LAB}$ strains grew under $\mathrm{pH} 2$ are the presumed acid tolerant LAB strains. However, all the 17 strains can be considered for probiotic strains, as the stomach acidic $\mathrm{pH}$ range from 1.5 to 3 . Tolerance to bile salts is commonly thought to be a prerequisite for LAB strains to survive in the small intestine (Azat et al.,2016) The average bile concentration in the human gastrointestinal tract is about $0.3 \%$, which is regarded critical and high enough to screen resistant strains (Azat et al.,2016). All the LAB isolates under the current study grew at a rate of more than $80 \%$ on $0.3 \%$ bile salt for 24 and 48 hours incubation (table 3). This finding is identical to (Damayanti et al.,2014), which had a viability percentage of greater than $100 \%$. Biliary salts, which are compounds capable of damaging bacterial cell membranes and DNA, are key antibacterial agents in the digestive system (Machado et al., 2014). In the gastric juice ( $\mathrm{pH} \mathrm{2,} \mathrm{2.5,} \mathrm{and} \mathrm{3)} \mathrm{tolerant} \mathrm{assay} \mathrm{all} \mathrm{the} \mathrm{LAB}$ isolates demonstrated cell viability percentages (Table 4) ranging from $50 \%$ to $69 \%$ after a 24-hours incubation at $\mathrm{pH} \mathrm{2,} \mathrm{with} \mathrm{the} \mathrm{exception} \mathrm{of} \mathrm{strain} \mathrm{C} 12$. However, after 24 hours of incubation, all the strains were able to show high survival rates of $81-89 \%$ at $\mathrm{pH} 2.5$ and 94$105 \%$ at $\mathrm{pH}$ 3. In a previous study, Bile Salt and Acid Tolerant of Lactic Acid Bacteria isolated from Proventriculus of broiler chicken had the highest viability at $\mathrm{pH} 2$ (40.8476.76\%) (Damayanti et al.,2014). However, the strains in this investigation had a lower survival rate (50\% to $69 \%)$ at $\mathrm{pH} 2$ after 24 hours.

The purpose of the simulated stomach duodenum passage test was to see how all of the components (bile, low $\mathrm{pH}$, and duodenal juice) worked together in a combined system. The majority of the isolates were able to survive this setting, indicating that they are able to reach the intestines. All of the isolates under investigation were still viable after 3 hours of exposure (table 5). Auto-aggregation was observed in all strains examined in this investigation (Table 6). After 24 hours, highest percentage of auto-aggregation was recorded, ranging from $12 \%$ to $83 \%$. Auto-aggregation was found to be somewhat lower in strains C15, C14, C13, C12 and C3. This result was comparable to that of (Krausova et al.,2019). In which all tested strains showed high auto-aggregation capacity after 24 hours of incubation, ranging from 21.7 to $69.7 \%$. The 17 selected potential probiotic lactic acid bacteria exhibited varying degrees of antagonism against Staphylococcus aureus, pseudomonas, Candida albicans and Escherichia coli (Table 7). According to Mulaw et al., (2019), isolates with clearance zones $\leq 9 \mathrm{~mm}$ and $\geq 12 \mathrm{~mm}$ diameter had low and significant antibacterial efficacy against the test pathogens, respectively. As a result, only 15 of the putative probiotic LAB strains tested showed high antibacterial activity against food-borne pathogens, with diameters 
ranging from $12 \pm 0.34$ to $26 \pm 0.34 \mathrm{~mm}$. C12 demonstrated low antimicrobial activity against Candida albicans, with an inhibition zone of $11.5 \pm 0.17 \mathrm{~mm}$, whereas $\mathrm{C} 1, \mathrm{C} 2$ and $\mathrm{C} 9 \mathrm{had}$ no activity against any of the pathogenic microbes tested. In agreement with the present study, (Mulaw et al., 2019).demonstrated that all Lactobacillus isolates obtained from Egyptian dairy products had a high level of antibacterial effect against $E$. coli and other pathogens with a zone of inhibition ranging from 19.33 to $21 \mathrm{~mm}$ in diameter.. LAB are capable of producing many types of bacteriocins such as Nisin, plantaricin and other bacteriocins. In this study, among all $17 \mathrm{LAB}$ isolates, 15 were found to be plantaricin gene-producing LAB with high zone of inhibition, which affirmed its potential as a strong antibacterial agent.

\section{Conclusion and recommendation}

The present study has shown that the seventeen strains of lactic acid bacteria isolated from "Tchoukou" traditional milk cheeses produced in selected region of Niger had desirable probiotic properties as they were tolerant to acid, bile, able to survive simulated stomach duodenum passage as well as inhibit test pathogenic microorganisms. Further in vivo studies should be carried out using cell lines and animal models with a view of developing a consumer product that can benefit society.

\section{Funding}

Financial support for this research was provided by the African Union through the Pan African University Institute of Basic Sciences, Technology and Innovation, (PAUSTI), Nairobi Kenya.

\section{Acknowledgements}

The authors are grateful to the Pan African University Institute for Basic Science, Technology and Innovation (PAUSTI) Nairobi Kenya, also more thanks to my supervisors and the Department of Food Science and Technology at Jomo Kenyatta University of Agriculture and Technology for providing all laboratory facilities and support throughout the project. The African Union provided financial support to the authors during the project, which they appreciate.

\section{REFERENCES:}

1. Anandharaj, M., \& Sivasankari, B. (2014). Isolation of potential probiotic Lactobacillus oris HMI68 from mother's milk with cholesterol-reducing property. Journal of Bioscience and Bioengineering, 118(2), 153-159. https://doi.org/10.1016/j.jbiosc.2014.01.015

2. Azat, R., Liu, Y., Li, W., \& Kayir, A. (2016). Probiotic properties of lactic acid bacteria isolated from traditionally fermented Xinjiang cheese *\#. 17(8), 597-609.

3. Balakrishna, A. (2013). In vitro evaluation of adhesion and aggregation abilities of four potential probiotic strains isolated from guppy (poecilia reticulata). Brazilian Archives of Biology and Technology, 56(5), 793-800. https://doi.org/10.1590/S151689132013000500010

4. Corcoran, B. M., Stanton, C., Fitzgerald, G. F., \& Ross, R. P. (2005). Survival of probiotic lactobacilli in acidic environments is enhanced in the presence of metabolizable sugars. Applied and Environmental Microbiology, 71(6), 3060-3067. https://doi.org/10.1128/AEM.71.6.3060-3067.2005

5. E. Damayanti, H. Julendra, A. Sofyan, and S. N. Hayati, "Bile Salt and Acid Tolerant 
of Lactic Acid Bacteria Isolated from Proventriculus of Broiler Chicken," vol. 37, no. August, pp. 80-86, 2014, doi: 10.5398/medpet.2014.37.2.80.

6. E. S. L. Chong, "A potential role of probiotics in colorectal cancer prevention: Review of possible mechanisms of action," World J. Microbiol. Biotechnol., vol. 30, no. 2, pp. 351-374, 2014, doi: 10.1007/s11274-013-1499-6.

7. G. Krausova, I. Hyrslova, and I. Hynstova, "In vitro evaluation of adhesion capacity, hydrophobicity, and auto-aggregation of newly isolated potential probiotic strains," Fermentation, vol. 5, no. 4, 2019, doi: 10.3390/fermentation5040100.

8. G. Mulaw, T. Sisay Tessema, D. Muleta, and A. Tesfaye, "In vitro evaluation of probiotic properties of lactic acid bacteria isolated from some traditionally fermented ethiopian food products," Int. J. Microbiol., vol. 2019, 2019, doi: $10.1155 / 2019 / 7179514$.

9. Jose, N. M., Bunt, C. R., \& Hussain, M. A. (2015). Comparison of microbiological and probiotic characteristics of lactobacilli isolates from dairy food products and animal rumen contents. Microorganisms, 3(2), 198-212. https://doi.org/10.3390/microorganisms3020198

10. J. Y. Lee, H. Kim, Y. Jeong, and C. H. Kang, "Lactic acid bacteria exert a hepatoprotective effect against ethanol-induced liver injury in hepg2 cells," Microorganisms, vol. 9, no. 9, 2021, doi: 10.3390/microorganisms9091844.

11. Lee, N. K., Kim, S. Y., Han, K. J., Eom, S. J., \& Paik, H. D. (2014). Probiotic potential of Lactobacillus strains with anti-allergic effects from kimchi for yogurt starters. LWT - Food Science and Technology, 58(1), 130-134. https://doi.org/10.1016/j.lwt.2014.02.028

12. Machado, F., Anna, D. E. S., Alvim, L. B., Castro, R. D. D. E., Oliveira, L. G. D. E., Marc, A., Silva, D. A., \& Souza, M. R. (2014). Assessment of the probiotic potential of lactic acid bacteria isolated from Minas artisanal cheese produced in the Campo das Vertentes region, Brazil. 1-10. https://doi.org/10.1111/1471-0307.12422

13. Mahmoud, M., Abdallah, N. A., El-Shafei, K., Tawfik, N. F., \& El-Sayed, H. S. (2020). Survivability of alginate-microencapsulated Lactobacillus plantarum during storage, simulated food processing and gastrointestinal conditions. Heliyon, 6(3). https://doi.org/10.1016/j.heliyon.2020.e03541

14. Mathara, J. M., Schillinger, U., Kutima, P. M., Mbugua, S. K., Guigas, C., Franz, C., \& Holzapfel, W. H. (2008). Functional properties of Lactobacillus plantarum strains isolated from Maasai traditional fermented milk products in Kenya. Current Microbiology, 56(4), 315-321. https://doi.org/10.1007/s00284-007-9084-6

15. Mulaw, G., Sisay Tessema, T., Muleta, D., \& Tesfaye, A. (2019). In vitro evaluation of probiotic properties of lactic acid bacteria isolated from some traditionally fermented ethiopian food products. International Journal of Microbiology, 2019. https://doi.org/10.1155/2019/7179514

16. M. Anandharaj and B. Sivasankari, "Isolation of potential probiotic Lactobacillus oris HMI68 from mother's milk with cholesterol-reducing property," J. Biosci. Bioeng., vol. 118, no. 2, pp. 153-159, 2014, doi: 10.1016/j.jbiosc.2014.01.015.

17. M. Del Piano et al., "Clinical experience with probiotics in the elderly on total enteral nutrition.," J. Clin. Gastroenterol., vol. 38, no. 6 Suppl, pp. 111-114, 2004, doi: 10.1097/01.mcg.0000128937.32835.7c.

18. N. K. Lee, S. Y. Kim, K. J. Han, S. J. Eom, and H. D. Paik, "Probiotic potential of Lactobacillus strains with anti-allergic effects from kimchi for yogurt starters," $L W T$ - 
Food Sci. Technol., vol. 58, no. 1, pp. 130-134, 2014, doi: 10.1016/j.lwt.2014.02.028.

19. Reuben, R. C., Roy, P. C., Sarkar, S. L., Rubayet Ul Alam, A. S. M., \& Jahid, I. K. (2020). Characterization and evaluation of lactic acid bacteria from indigenous raw milk for potential probiotic properties. Journal of Dairy Science, 103(2), 1223-1237. https://doi.org/10.3168/jds.2019-17092

20. Ridwan, B. U., Koning, C. J. M., Besselink, M. G. H., Timmerman, H. M., Brouwer, E. C., Verhoef, J., Gooszen, H. G., \& Akkermans, L. M. A. (2008). Antimicrobial activity of a multispecies probiotic (Ecologic 641) against pathogens isolated from infected pancreatic necrosis. Letters in Applied Microbiology, 46(1), 61-67. https://doi.org/10.1111/j.1472-765X.2007.02260.x

21. R. Azat, Y. Liu, W. Li, and A. Kayir, "Probiotic properties of lactic acid bacteria isolated from traditionally fermented Xinjiang cheese *\#," vol. 17, no. 8, pp. 597609, 2016.

22. Smid, E. J., Van Enckevort, F. J. H., Wegkamp, A., Boekhorst, J., Molenaar, D., Hugenholtz, J., Siezen, R. J., \& Teusink, B. (2005). Metabolic models for rational improvement of lactic acid bacteria as cell factories. Journal of Applied Microbiology, 98(6), 1326-1331. https://doi.org/10.1111/j.1365-2672.2005.02652.x

23. S. S. Grosu-Tudor and M. Zamfir, "Probiotic potential of some lactic acid bacteria isolated from Romanian fermented vegetables," Ann. Rom. Soc. Cell Biol., vol. 17, no. 1, pp. 234-239, 2012.

24. Tan, Q., Xu, H., Aguilar, Z. P., Peng, S., Dong, S., Wang, B., Li, P., Chen, T., Xu, F., \& Wei, H. (2013). Safety Assessment and Probiotic Evaluation of Enterococcus Faecium YF5 Isolated from Sourdough. Journal of Food Science, 78(4). https://doi.org/10.1111/1750-3841.12079

25. Yadav, R., Puniya, A. K., \& Shukla, P. (2016). Probiotic properties of Lactobacillus plantarum RYPR1 from an indigenous fermented beverage Raabadi. Frontiers in Microbiology, 7(OCT), 1-9. https://doi.org/10.3389/fmicb.2016.01683 